\title{
Pengolahan Limbah Cair Domestik untuk Penggunaan Ulang (Water Reuse)
}

\author{
Yunita Mulyana ${ }^{1}$, Rizki Purnaini ${ }^{2}$, Berlian Sitorus ${ }^{3}$ \\ Program Studi : Teknik Lingkungan, Universitas Tanjungpura, Pontianak \\ Email : ayu_yura@yahoo.co.id
}

\begin{abstract}
ABSTRAK
Pengolahan limbah cair domestik akan menghasilkan dua keuntungan, yakni mengatasi masalah pencemaran lingkungan, sekaligus mempromosikan penggunaan limbah cair dari rumah tangga sebagai sumber daya air bersih yang baru bagi masyarakat. Tujuan dari penelitian ini adalah mendapatkan suatu sistem pengolahan limbah cair berskala laboratorium yang dapat digunakan untuk mengolah limbah cair domestik dan menghasilkan efluen yang dapat memenuhi persyaratan baku mutu air yang layak untuk digunakan kembali. Sampel limbah cair dimasukkan kedalam wadah ember plastik sebagai reaktor. Reaktor dibiarkan terbuka dan dilengkapi dengan aerator. Setelah itu limbah cair yang keluar (effluent) dari reaktor dialirkan menuju alat filtrasi atau penyaringan dan terakhir dialirkan menuju bak desinfeksi untuk membunuh atau mengurangi mikroorganisme patogen dengan menggunakan desinfeksi oleh sinar UV dari matahari. Perubahan kandungan COD, TSS dan Total Koliform limbah cair rumah tangga mengalami pengurangan setelah melalui proses pengolahan secara aerobik selama 3 hari dilanjutkan dengan filtrasi dan desinfeksi dengan sinar UV, dimana kandungan COD awal limbah adalah 257,5 mg/L dan setelah diolah adalah $21 \mathrm{mg} / \mathrm{L}$., TSS awal limbah adalah $372,5 \mathrm{mg} / \mathrm{L}$ dan setelah diolah adalah $2 \mathrm{mg} / \mathrm{L}$ dan kandungan Total Koliform awal limbah adalah $110 \times 10^{4} \mathrm{MPN} / 100 \mathrm{ml}$ dan setelah diolah adalah $\geq 1600 \mathrm{MPN} / 100 \mathrm{ml}$.
\end{abstract}

Kata kunci: limbah cair domestik, aerobik, penggunaan ulang

\begin{abstract}
Wastewater treatment will yield two benefits, resolve the problem of environmental pollution caused by domestic waste, while promoting the use of domestic wastewater as a new water resource for the community. The purpose of this study is to get a wastewater treatment system in laboratory scale that used to process domestic wastewater and produce effluent that can meet the requirements of appropriate water quality standards for reuse. Influent sample was taken then put into a plastic bucket as the reactor. The reactor was left open and equipped with aerator. After that effluent from the reactor flowed towards filtration or screening tools and streamed toward the disinfection tub to kill or reduce pathogenic microorganisms using a disinfection by UV rays from the sun. Changes in COD, TSS and Total Coliform content of domestic wastewater has decreased after aerobic treatment processes for 3 days followed by filtration and disinfection with UV light, in which the initial COD content of wastewater was $257,5 \mathrm{mg} / \mathrm{L}$ and after treatment was $21 \mathrm{mg} / \mathrm{L}$, TSS content of the waste was 372,5 $\mathrm{mg} / \mathrm{L}$ and after treatment is 2 $\mathrm{mg} / \mathrm{L}$, Total Coliform initial waste is $110 \times 10^{4} \mathrm{MPN} / 100 \mathrm{ml}$ and after treatment was $\geq 1600 \mathrm{MPN} / 100 \mathrm{ml}$.
\end{abstract}

Keywords: domestic wastewater, aerobic, water reuse

\section{Pendahuluan}

Dewasa ini air menjadi masalah yang perlu mendapat perhatian yang seksama dan cermat. Karena untuk mendapatkan air yang bersih, sesuai dengan standar tertentu, saat ini menjadi barang yang mahal karena air sudah banyak tercemar oleh bermacam-macam limbah dari hasil kegiatan manusia, baik limbah dari kegiatan rumah tangga, limbah dari kegiatan industri dan kegiatan-kegiatan lainnya. Dan 
ketergantungan manusia terhadap air pun semakin besar sejalan dengan perkembangan penduduk yang semakin meningkat.

Limbah cair rumah tangga atau domestik adalah air buangan yang berasal dari penggunaan untuk kebersihan yaitu gabungan limbah dapur, kamar mandi, toilet, cucian, dan sebagainya (Puji dan Nur Rahmi, 2009). Komposisi limbah cair rata-rata mengandung bahan organik dan senyawa mineral yang berasal dari sisa makanan, urin, dan sabun. Sebagian limbah rumah tangga berbentuk suspensi, lainnya dalam bentuk bahan terlarut. Di kota besar misalnya, beban organik (organic load) limbah cair domestik dapat mencapai sekitar $70 \%$ dari beban organik total limbah cair yang ada dikota tersebut. Limbah cair rumah tangga memiliki karakteristik yaitu TSS 25-183 mg/l, COD 100-700 mg/l, BOD 47-466 mg/l, Total Coliforms $56-8,03 \times 10^{7} \mathrm{CFU} / 100 \mathrm{ml}$ (Li, 2009).

Tuntutan pada sumber daya air untuk rumah tangga, komersial, industri, dan pertanian meningkat sangat pesat. Menurut S. Vigneswaran dan M. Sundaravadivel (2004) populasi manusia di dunia akan tumbuh 1,5 kali lebih pada pertengahan abad kedua puluh satu, tapi penggunaan air di seluruh dunia meningkat lebih dari tiga kali pertumbuhan penduduk. Di sebagian besar negara populasi manusia semakin bertambah sementara air yang tersedia tetap. Dari 100 negara yang disurvei oleh World Resources Institute pada tahun 1986, lebih dari setengah dinilai memiliki ketersediaan air rendah sampai sangat rendah, dan kualitas air telah menjadi isu utama untuk rendahnya ketersediaan air bersih. Nilai dari penggunaan ulang air limbah menjadi semakin dipahami oleh masyarakat, baik di negara maju maupun negara berkembang dan banyak negara sekarang mencari cara untuk meningkatkan dan memperluas praktek-praktek penggunaan ulang air tersebut.

Limbah cair domestik yang merupakan air buangan rumah tangga sangat berpotensi menjadi salah satu sumber air yang baru. Pengolahan limbah cair untuk penggunaan ulang dapat mengurangi tingkat pencemaran lingkungan yang disebabkan oleh limbah cair domestik, serta mempromosikan penggunaan limbah cair dari rumah tangga sebagai sumber air bersih yang baru bagi masyarakat.

Dalam penelitian ini akan dilakukan pengolahan secara biologi dan fisika, yaitu aerasi dengan penambahan bakteri EM4 secara biologi dan dengan sistem filtrasi secara fisika. Proses aerasi sangat penting terutama pada pengolahan limbah yang proses pengolahan biologinya memanfaatkan bakteri aerob. Bakteri aerob adalah kelompok bakteri yang mutlak memerlukan oksigen bebas untuk proses metabolismenya. Dengan tersedianya oksigen yang mencukupi selama proses biologi, maka bakteribakteri tersebut dapat bekerja dengan optimal. Menurut Arsawan dkk. (2007), pengurangan terbesar kandungan COD dari limbah berminyak diperoleh setelah diaerasi selama 72 jam. Sementara pengurangan terbesar kandungan TSS diperoleh setelah proses aerasi selama 24 jam. Susilawaty dkk. (2007) pada penelitiannya terhadap limbah cair rumah tangga menyatakan bahwa sistem filtrasi menggunakan pasir dan karbon aktif dapat menurunkan nilai TSS sebesar 93,9\%, COD 76,1\%, fosfat 90,2\%. Desinfeksi atau pembunuhan kuman bertujuan untuk membunuh atau mengurangi mikroorganisme patogen yang ada dalam limbah cair. Menurut Agrijanti (2008) air yang dijemur selama 4 sampai 5 jam dan mencapai suhu $50^{\circ} \mathrm{C}$ terbukti dapat membunuh seluruh bakteri yang terkandung didalamnya dengan bantuan pemanasan dan sinar ultra violet dari matahari.

Oleh karena itu, dalam penelitian ini akan dilakukan pengolahan limbah cair rumah tangga khususnya grey water secara biologi-fisika dengan mengabungkan metode aerasi dan filtrasi kemudian dilanjutkan dengan desinfeksi ultra violet dari sinar matahari. Dari hasil ini diharapkan limbah cair hasil pengolahan dapat memenuhi baku mutu limbah cair dalam beberapa parameter yang diamati.

\section{Metodologi}

\section{A. Alat dan Bahan Penelitian}

Bahan yang digunakan dalam penelitian ini yaitu limbah cair domestik. Sedangkan bahan-bahan yang digunakan untuk uji kualitas air limbah baik sebelum diolah maupun setelah diolah yaitu meliputi akuades, asam sulfat $\left(\mathrm{H}_{2} \mathrm{SO}_{4}\right)$, ferro amonium sulfat (FAS) [ $\mathrm{Fe}\left(\mathrm{NH}_{4}\right)_{2}\left(\mathrm{SO}_{4}\right)_{2} \cdot 6 \mathrm{H}_{2} \mathrm{O}$ ], kalium dikromat 
$\left(\mathrm{K}_{2} \mathrm{Cr}_{2} \mathrm{O}_{7}\right)$, kertas saring Whatman, $\mathrm{FeSO}_{4} \cdot 7 \mathrm{H}_{2} \mathrm{O}$, merkuri sulfat $\left(\mathrm{HgSO}_{4}\right)$, perak sulfat $\left(\mathrm{Ag}_{2} \mathrm{SO}_{4}\right)$, batu didih, dan 1,10 phenantrolin monohidrat.

Alat-alat yang digunakan dalam penelitian pengolahan limbah cair domestik : reaktor untuk pembuatan starter bakteri, pengolahan biologi, pengolahan fisika, dan pengolahan kimia. Untuk reaktor starter bakteri dibuat menggunakan wadah ember plastik ukuran 5 liter. Untuk reaktor pengolahan biologii dibuat menggunakan wadah drum plastik kapasitas 10 liter. Alat aerasi berupa pompa akuarium. Alat penyaring untuk pengolahan fisika berbentuk tabung dan diisi dengan pasir, batu kerikil, dan karbon aktif. Bak desinfeksi untuk pengolahan kimia berupa kotak kaca dengan kapasitas 13,5 liter.

Alat-alat yang digunakan untuk analisis hasil peralatan refluks, labu ukur $100 \mathrm{~mL}$ dan $1000 \mathrm{~mL}$, buret $25 \mathrm{~mL}$, pipet volum $10 \mathrm{~mL}$, Erlenmeyer $250 \mathrm{~mL}$, neraca analitis, desikator, oven, gelas ukur, alat penyaring, krus porselen, penjepit, oven, pompa akuarium, pompa vakum.

\section{B. Metode Penelitian}

Sampel limbah cair domestik khususnya grey water untuk bahan penelitian diambil dari outlet saluran pembuangan air buangan rumah kos yang berlokasi di Kecamatan Pontianak Selatan. Sampel limbah cair diambil secara grab sampling. Tahap awal dari penelitian ini yaitu pembuatan starter bakteri aerob. Sampel limbah cair yang sudah di ambil 1,8 liter selanjutnya dimasukkkan ke dalam wadah ember plastik ukuran 5 liter. Pada air limbah ditambahkan EM 4 sebanyak $100 \mathrm{ml}$ dan molase sebanyak $100 \mathrm{ml}$ dan diberi aerator serta ember tidak ditutup agar tercipta kondisi aerob, kemudian keadaan ini dibiarkan selama 1 minggu. Tujuan dari pembuatan starter ini adalah untuk mengembangbiakan bakteri aerob yang sudah terkondisi dengan sampel limbah cair domestik yang ada, sehingga selanjutnya untuk proses pengolahan limbah cair pada reaktor yang akan dibuat, bakteri yang ada sudah dapat menyesuaikan diri dan langsung dapat bekerja dengan baik. Selanjutnya limbah cair domestik sebanyak 10 liter dimasukkan ke dalam reaktor pengolahan aerob. Kemudian dimasukkan bakteri yang telah distarter sebanyak 1 liter. Pada percobaan pengolahan limbah cair kondisi aerob ini, reaktor dibiarkan terbuka dan reaktor dilengkapi dengan aerator.

Setelah itu limbah cair yang keluar (effluent) dari reaktor dialirkan menuju alat filtrasi atau penyaringan berupa pasir halus, pasir kasar, ijuk, batu kerikil dan karbon aktif dengan susunan dan tinggi masing-masing : pasir halus $=15 \mathrm{~cm}$, pasir kasar $=15 \mathrm{~cm}$, batu kerikil $=10 \mathrm{~cm}$ dan yang terakhir adalah karbon aktif dengan tinggi $10 \mathrm{~cm}$ dan terakhir dialirkan menuju bak disinfeksi untuk membunuh atau mengurangi mikroorganisme patogen yang masih terdapat pada efluen dari proses filtrasi dengan

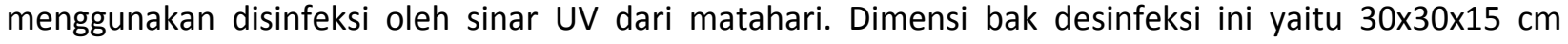
dengan lama waktu penyinaran yaitu 6 jam.

\section{Hasil dan Pembahasan}

\section{A. Hasil Pengolahan Limbah secara Aerobik}

Pada Tabel 1 terlihat bahwa kandungan COD limbah cair rumah tangga mengalami pengurangan setelah melalui proses pengolahan secara aerobik selama 3 hari, dimana kandungan COD awal limbah yaitu sebesar 257,5 mg/L dan setelah diolah turun menjadi $21 \mathrm{mg} / \mathrm{L}$. Terjadinya pengurangan tersebut dikarenakan bakteri aerobik yang ada di dalam reaktor menguraikan senyawa-senyawa organik yang ada di dalam limbah cair rumah tangga (Sudaryati dkk., 2007). Terurainya senyawa-senyawa organik tersebut mengakibatkan nilai COD menurun, karena menurut Fatha (2007) tingginya nilai COD dalam limbah cair rumah tangga sebagian besar disebabkan oleh adanya senyawa-senyawa organik seperti protein, karbohidrat dan lemak. Kandungan COD dari limbah cair rumah tangga mengalami penurunan setelah proses aerasi. Menurut Purwanti dkk (2003), berkurangnya kandungan COD tersebut disebabkan kandungan karbon dalam zat organik di dalam limbah terurai menjadi karbondioksida yang dikeluarkan ke lingkungan, hal inilah yang menyebabkan kandungan COD setelah proses aerasi menurun dibandingkan kandungan awalnya. Pada aerasi dengan waktu retensi 3 hari, nilai COD dari aerobik 1 hari 
yaitu $155 \mathrm{mg} / \mathrm{l}$, turun pada saat aerobik 2 hari menjadi $57 \mathrm{mg} / \mathrm{l}$, dan luaran pada aerobik 3 hari menurun menjadi $51 \mathrm{mg} / \mathrm{L}$ yang disebabkan waktu kotak dengan udara yang semakin lama, sehingga nilai COD dari luaran menjadi turun.

Parameter kedua yang diamati dalam penelitian ini adalah kandungan TSS. Pada Tabel 4.3 terlihat bahwa kandungan TSS limbah cair rumah tangga mengalami pengurangan setelah melalui proses aerobik selama 3 hari, dimana kandungan TSS awal limbah adalah 372,5 mg/L dan setelah diolah turun menjadi 6 $\mathrm{mg} / \mathrm{L}$. Pengurangan ini terjadi disebabkan oleh terdegradasinya senyawa-senyawa organik yang ada di dalam limbah oleh bakteri. Oleh karena senyawa-senyawa tersebut telah terdegradasi, jumlah padatan yang ada di dalam limbah menjadi berkurang.

Dari Gambar 1 terlihat bahwa nilai TSS luaran dari proses aerobik 1 hari, aerobik 2 hari maupun nilai TSS limbah setelah proses aerobik selama 3 hari menunjukkan penurunan, yakni dari $164 \mathrm{mg} / \mathrm{L}$ pada saat aerobik 1 hari, turun menjadi $54 \mathrm{mg} / \mathrm{L}$ pada proses aerobik 2 hari dan pada aerobik 3 hari turun menjadi $6 \mathrm{mg} / \mathrm{L}$. Hal ini sejalan dengan Arsawan dkk. (2007) yang menyatakan bahwa pemberian oksigen ke dalam limbah cair dapat menghancurkan endapan-endapan yang tergumpal sehingga akan mempermudah penyerapan oksigen yang menyebabkan bakteri-bakteri aerob yang berfungsi sebagai pengurai dapat bertumbuh dengan baik sehingga semakin banyak bakteri pengurai yang dapat menguraikan endapan-endapan yang tergumpal dan nilai TSS menjadi turun.

Nilai kandungan COD dan TSS limbah cair domestik setelah proses aerobik ditunjukkan dalam Tabel 1 , sedangkan grafik nilai kandungan COD dan TSS luaran dari proses aerobik yang dialurkan terhadap waktu retensi ditunjukkan pada Gambar 1 dan Gambar 2.

Tabel 1 Nilai Kandungan COD dan TSS Luaran Hasil Perlakuan Proses Aerobik

\begin{tabular}{cccc}
\hline Perlakuan & Keterangan & $\begin{array}{c}\text { COD } \\
(\mathbf{m g} / \mathrm{L})\end{array}$ & $\begin{array}{c}\text { TSS } \\
(\mathbf{m g} / \mathrm{L})\end{array}$ \\
\hline A1 & Aerobik (1 hari) & 155 & 164 \\
A2 & Aerobik (2 hari) & 57 & 54 \\
A3 & Aerobik (3 hari) & 51 & 6 \\
\hline $\begin{array}{c}\text { Baku Mutu Kelas II } \\
\text { (PP RI No.82 Th. 2001) }\end{array}$ & & 25 & 50 \\
\hline
\end{tabular}

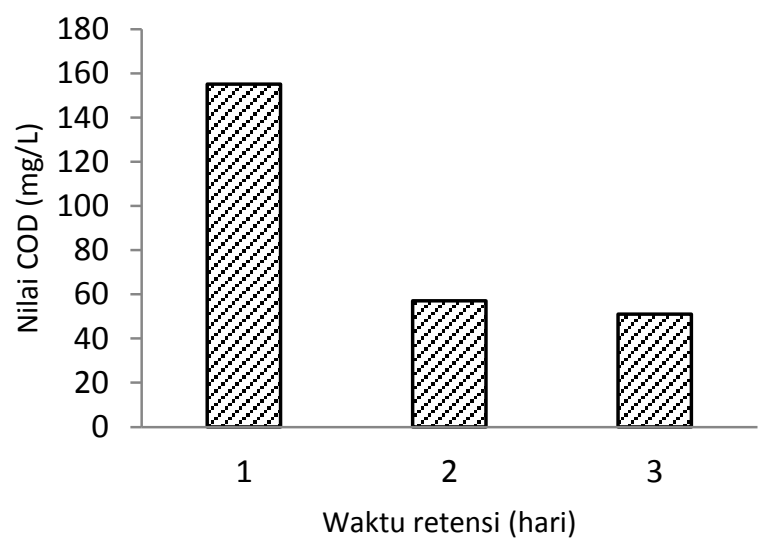

Gambar 1 Grafik nilai kandungan COD luaran dari proses aerobik terhadap waktu retensi 


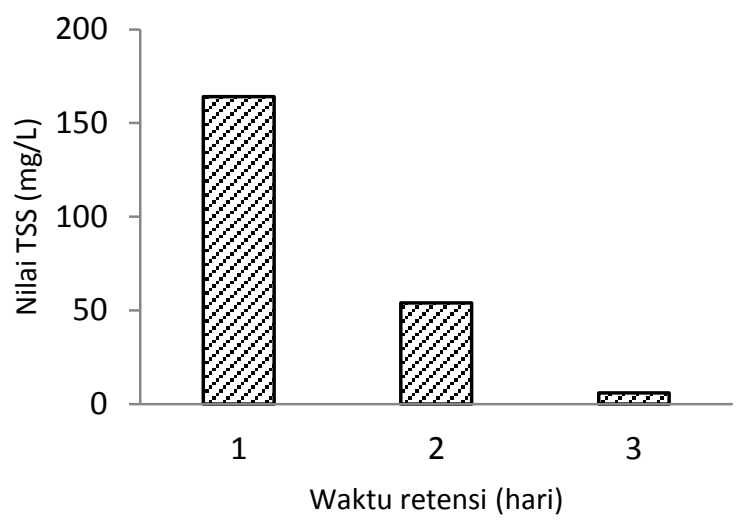

Gambar 2 Grafik nilai kandungan TSS luaran dari proses aerobik terhadap waktu retensi

B. Hasil Pengolahan Limbah secara Aerobik dilanjutkan dengan Filtrasi

Proses filtrasi menyebabkan penurunan nilai COD limbah cair rumah tangga, dari nilai awal pada saat aerobik hari pertama dilanjutkan dengan filtrasi yaitu sebesar $49 \mathrm{mg} / \mathrm{l}$ turun sehingga kandungan COD-nya menjadi $36 \mathrm{mg} / \mathrm{L}$ pada aerobik hari ketiga dilanjutkan dengan filtrasi. Menurut Tabatabaei et al. (2007), pengurangan kandungan COD dalam limbah cair disebabkan oleh terdegradasinya senyawasenyawa organik yang ada di dalam limbah oleh bakteri yang terperangkap dilapisan pasir. Oleh karena senyawa-senyawa tersebut telah terdegradasi, maka kandungan COD pada limbah berkurang setelah melewati media filter.

Parameter kedua yang diamati dalam penelitian ini adalah kandungan TSS. Pada Tabel 2 terlihat bahwa kandungan TSS limbah cair rumah tangga mengalami penurunan setelah melalui proses aerobik 1 hari hingga 3 hari dan dilanjutkan dengan filtrasi, dimana kandungan TSS awal limbah adalah 372,5 mg/L dan setelah diolah turun menjadi $5 \mathrm{mg} / \mathrm{L}$. Penurunanan ini terjadi disebabkan oleh tertahannya partikelpartikel padatan yang ada di dalam limbah oleh media filter pada saat proses filtrasi. Tertahannya partikel-partikel padatan oleh media filter tersebut menyebabkan jumlah padatan yang ada di dalam limbah menjadi berkurang.

Nilai TSS luaran dari proses filtrasi menunjukkan penurunan, pada aerobik hari pertama dilanjutkan dengan filtrasi yang semula memiliki nilai TSS sebesar $38 \mathrm{mg} / \mathrm{L}$, berkurang menjadi $5 \mathrm{mg} / \mathrm{L}$ setelah melalui proses aerobik hari ketiga dilanjutkan dengan filtrasi. Hal ini disebabkan partikel-partikel padatan di dalam limbah tertahan oleh media yang digunakan dalam proses filtrasi. Pada penelitian ini proses filtrasi terjadi di dalam media pasir, sementara proses adsorpsi terjadi pada batu kerikil dan karbon aktif. Batu kerikil dan karbon aktif dapat mengadsorpsi partikel karena memiliki pori-pori.

Nilai kandungan COD dan TSS limbah cair domestik setelah proses aerobik dilanjutkan dengan filtrasi ditunjukkan dalam Tabel 2 , sedangkan grafik nilai kandungan COD dan TSS luaran dari proses aerobik dilanjutkan dengan filtrasi yang dialurkan terhadap waktu retensi ditunjukkan pada Gambar 3 dan Gambar 4. 
Tabel 2 Nilai Kandungan COD dan TSS Luaran Hasil Perlakuan Proses Aerobik dilanjutkan dengan Filtrasi

\begin{tabular}{cccc}
\hline Perlakuan & Keterangan & $\begin{array}{c}\text { COD } \\
(\mathrm{mg} / \mathrm{L})\end{array}$ & $\begin{array}{c}\text { TSS } \\
(\mathrm{mg} / \mathrm{L})\end{array}$ \\
\hline B1 & Aerobik (1 hari) + Filtrasi & 49 & 38 \\
B2 & Aerobik (2 hari) + Filtrasi & 42 & 6 \\
B3 & Aerobik (3 hari) + Filtrasi & 36 & 5 \\
\hline $\begin{array}{c}\text { Baku Mutu Kelas II } \\
\text { (PP RI No.82 Th. 2001) }\end{array}$ & & 25 & 50 \\
\hline
\end{tabular}

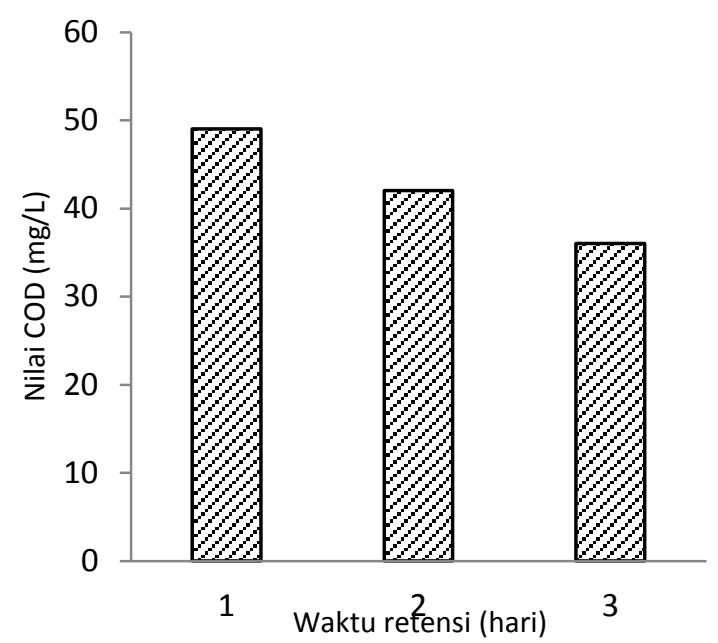

Gambar 3 Grafik nilai kandungan COD luaran dari proses aerobik dilanjutkan dengan filtrasi terhadap waktu retensi

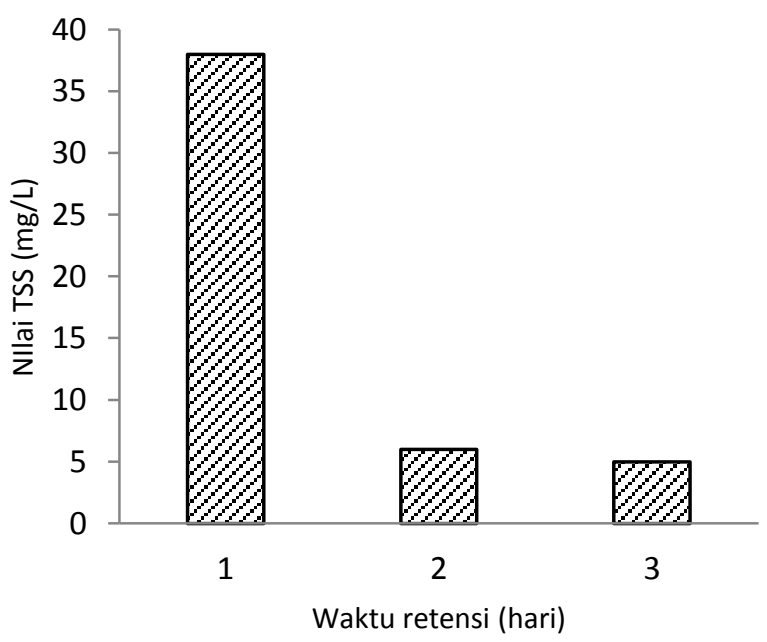

Gambar 4 Grafik nilai kandungan TSS luaran dari proses aerobik dilanjutkan dengan filtrasi terhadap waktu retensi 
C. Hasil Pengolahan Limbah secara Aerobik dilanjutkan dengan Filtrasi dan Desinfeksi Sinar UV Matahari

Proses desinfeksi dengan sinar UV matahari menyebabkan penurunan nilai COD limbah cair rumah tangga dari nilai awal pada proses aerobik 1 hari dilanjutkan dengan fitrasi dan desinfeksi UV sebesar 36 $\mathrm{mg} / \mathrm{l}$ hingga kandungan COD-nya menjadi $21 \mathrm{mg} / \mathrm{L}$ pada aerobik 3 hari dilanjutkan dengan fitrasi dan desinfeksi UV. Menurut Tabatabaei et al. (2007), pengurangan kandungan COD dalam limbah cair disebabkan oleh kandungan karbon yang terurai oleh sinar ultra violet yang berasal dari matahari.

Nilai COD air limbah hasil pengolahan apabila dibandingkan dengan Peraturan Pemerintah No. 82 Tahun 2001 tentang Pengelolaan Kualitas Air dan Pengendalian Pencemaran Air telah memenuhi baku mutu kelas II yaitu sebesar $25 \mathrm{mg} / \mathrm{L}$, dimana nilai COD air limbah hasil pengolahan berada dibawah baku mutu yaitu sebesar $21 \mathrm{mg} / \mathrm{L}$.

Dari Tabel 3 terlihat bahwa nilai TSS luaran dari proses aerobik 1 hari, aerobik 2 hari maupun nilai TSS limbah setelah proses aerasi selama 3 hari dilanjutkan dengan filtrasi dan desinfeksi menunjukkan penurunan, yakni dari $6 \mathrm{mg} / \mathrm{l}$ pada saat hari pertama, turun menjadi $3 \mathrm{mg} / \mathrm{l}$ pada hari kedua dan pada hari ketiga turun menjadi $2 \mathrm{mg} / \mathrm{L}$.

Adapun nilai TSS air limbah hasil pengolahan apabila dibandingkan dengan Peraturan Pemerintah No. 82 Tahun 2001 tentang Pengelolaan Kualitas Air dan Pengendalian Pencemaran Air maka memenuhi baku mutu kelas II yaitu sebesar $50 \mathrm{mg} / \mathrm{L}$, dimana nilai TSS air limbah hasil pengolahan yang dihasilkan nilainya dibawah baku mutu yaitu sebesar $2 \mathrm{mg} / \mathrm{L}$. sedangkan apabila dibandingkan dengan Keputusan Menteri Negara Lingkungan Hidup No. 112 Tahun 2003 tentang Baku Mutu Air Limbah Domestik maka nilai TSS air limbah hasil pengolahan telah jauh memenuhi baku mutu, dimana baku mutu untuk parameter TSS yaitu $100 \mathrm{mg} / \mathrm{L}$ sedangkan nilai TSS air limbah hasil pengolahan yaitu sebesar 2 . Nilai kandungan COD dan TSS limbah cair domestik setelah proses aerobik dilanjutkan dengan filtrasi ditunjukkan dalam Tabel 3, sedangkan grafik nilai kandungan COD dan TSS luaran dari proses aerobik dilanjutkan dengan filtrasi yang dialurkan terhadap waktu retensi ditunjukkan pada Gambar 5 dan Gambar 6.

Tabel 3 Nilai Kandungan COD dan TSS Luaran Hasil Perlakuan Proses Aerobik dilanjutkan dengan Filtrasi dan Desinfeksi UV

\begin{tabular}{cccc}
\hline Perlakuan & Keterangan & $\begin{array}{c}\text { COD } \\
(\mathbf{m g} / \mathrm{L})\end{array}$ & $\begin{array}{c}\text { TSS } \\
(\mathbf{m g} / \mathrm{L})\end{array}$ \\
\hline C1 & Aerobik (1 hari) + Filtrasi + UV & 36 & 6 \\
C2 & Aerobik (2 hari) + Filtrasi + UV & 30 & 3 \\
C3 & Aerobik (3 hari) + Fitrasi + UV & 21 & 2 \\
\hline $\begin{array}{c}\text { Baku Mutu Kelas II } \\
\text { (PP RI No.82 Th. 2001) }\end{array}$ & & 25 & 50 \\
\hline
\end{tabular}




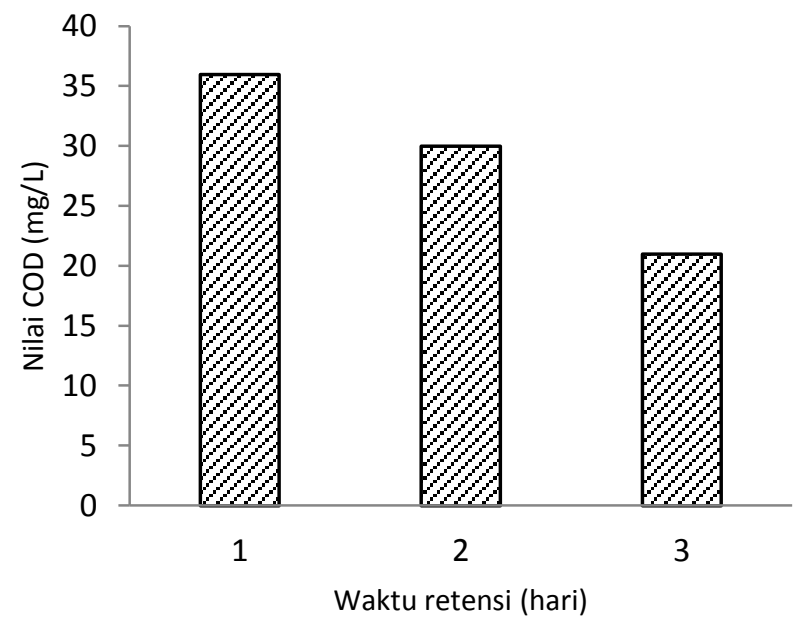

Gambar 5 Grafik nilai kandungan COD luaran dari proses aerobik dilanjutkan dengan filtrasi terhadap waktu retensi

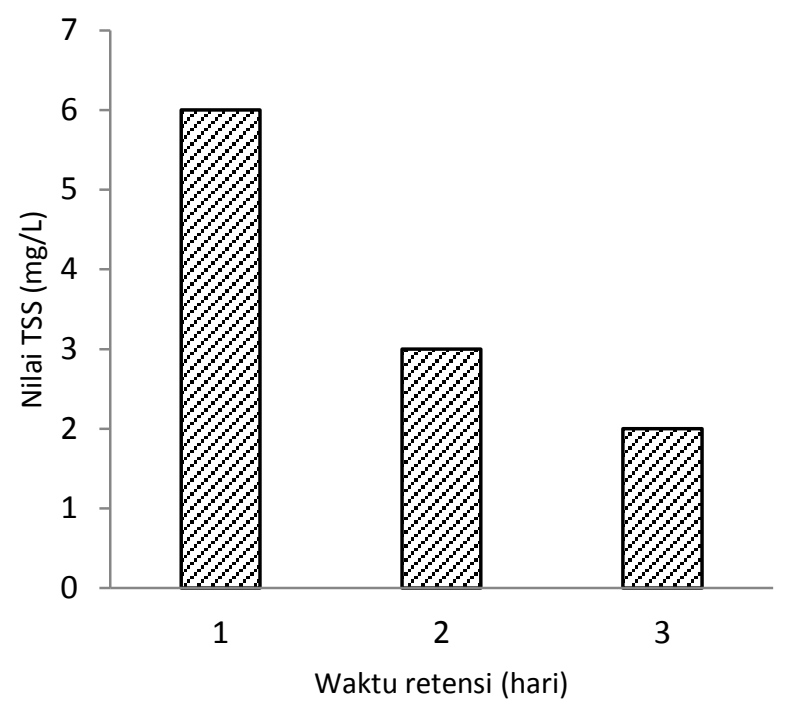

Gambar 6 Grafik nilai kandungan TSS luaran dari proses aerobik dilanjutkan dengan filtrasi terhadap waktu retensi

Parameter ketiga yang diamati pada penelitian ini yaitu total koliform. Pada Tabel 4 terlihat bahwa kandungan Total Koliform limbah cair rumah tangga mengalami pengurangan setelah melalui proses pengolahan secara aerobik selama 3 hari yang kemudian dilanjutkan dengan filtrasi dan diakhiri dengan desinfeksi, dimana kandungan Total Koliform awal limbah adalah $110 \times 10^{4} \mathrm{MPN} / 100 \mathrm{ml}$ dan setelah diolah turun menjadi $1600 \mathrm{MPN} / 100 \mathrm{ml}$.

Tabel 4 Nilai Kandungan Total Koliform Luaran Hasil Perlakuan Proses Aerobik, Filtrasi dan Desinfeksi UV

\begin{tabular}{ccc}
\hline Perlakuan & $\begin{array}{c}\text { Total Koliform (MPN/100 } \\
\text { ml) }\end{array}$ & Baku Mutu \\
\hline Awal & $110 \times 10^{4}$ & 5000 \\
Aerobik (3 hari) + Filtrasi + UV & $\geq 1600$ & \\
\hline
\end{tabular}


Proses desinfeksi dilakukan dengan meletakkan air luaran dari proses aerobik 3 hari yang dilanjutkan dengan filtrasi kedalam bak desinfeksi berukuran $30 \times 30 \times 15 \mathrm{~cm}$ dengan ketinggian air 2,3 $\mathrm{cm}$. Bak desinfeksi kemudian diletakkan di tepi jendela yang terbuka dan terkena paparan sinar matahari. Pemaparan sinar matahari yaitu selama 6 jam. Menurut Acra dkk pemaparan sinar matahari selama 2 jam dapat menyebabkan destruksi total populasi Koliform sebanyak $71 \mathrm{sel} / \mathrm{ml}$. Daya bakterisida sinar matahari terjadi melalui reaksi fotooksidasi yang menyebabkan destruksi oksidatif materi organik sehingga unsur-unsur utama sel seperti asam nukleat, lipid, protein dan polisakarida mengalami perubahan irreversibel. Hal tersebut menyebabkan semua perkembangan biologis terhambat dan menyebabkan kematian mikroba. Menurut Agrijanty (2008), air yang dijemur selama 4 jam sampai 5 jam telah mampu mencapai suhu $50^{\circ} \mathrm{C}$ terbukti dapat membunuh seluruh bakteri yang terkandung didalamnya dengan bantuan pemanasan dari sinar ultra violet dari matahari.

Adapun nilai Total Koliform air limbah hasil pengolahan apabila dibandingkan dengan Peraturan Pemerintah No. 82 Tahun 2001 tentang Pengelolaan Kualitas Air dan Pengendalian Pencemaran Air maka memenuhi baku mutu kelas II yaitu sebesar 5000 MPN/100 ml, dimana nilai Total Koliform air limbah hasil pengolahan yang dihasilkan nilainya dibawah baku mutu yaitu sebesar $\geq 1600 \mathrm{MPN} / 100 \mathrm{ml}$.

\section{Kesimpulan}

1. Karakteristik limbah cair domestik khususnya grey water yaitu memiliki kandungan COD sebesar $257,5 \mathrm{mg} / \mathrm{L}$, TSS sebesar $372,5 \mathrm{mg} / \mathrm{L}$ dan Total Koliform sebesar $110 \times 10^{4} \mathrm{MPN} / 100 \mathrm{ml}$

2. Sistem pengolahan untuk limbah cair domestik yaitu secara aerob dengan kombinasi pengolahan secara biologi yaitu di aerasi, kemudian dilanjutkan dengan pengolahan secara fisika yaitu dengan filtrasi dan diakhiri dengan desinfeksi oleh sinar UV matahari dapat menghasilkan effluent yang memenuhi standar baku mutu limbah domestik yang boleh dibuang ke lingkungan sesuai dengan Keputusan Menteri Negara Lingkungan Hidup No. 112 Tahun 2003 dan dapat digunakan ulang sesuai dengan Peraturan Pemerintah No. 82 Tahun 2001 tentang Pengelolaan Kualitas Air dan Pengendalian Pencemaran Air baku mutu kelas II.

3. Kondisi terbaik sistem pengolahan limbah cair domestik yaitu setelah melalui proses aerob selama 3 hari dan dilanjutkan dengan filtrasi dan desinfeksi dengan sinar UV matahari. Luaran hasil pengolahan yaitu COD menjadi $21 \mathrm{mg} / \mathrm{L}$, TSS menjadi $2 \mathrm{mg} / \mathrm{L}$ dan total koliform setelah diolah menjadi $1600 \mathrm{MPN} / 100 \mathrm{ml}$.

\section{Ucapan Terima Kasih}

Ucapan terima kasih yang tak terhingga kepada Ibu Rizki Purnaini, ST., MT. selaku pembimbing pertama dan Ibu Berlian Sitorus, M.Si., M.Sc selaku pembimbing kedua yang telah meluangkan waktu dan pikiran untuk memberikan dorongan serta bimbingan, mulai dari penelusuran pustaka, pelaksanaan penelitian hingga penulisan jurnal ini.

\section{Referensi}

Agrijanty, Lina Sundayani, L.B. Kusuma Dewi. 2008. Pengaruh Volume terhadap Pertumbuhan Mikroba pada Desinfeksi Air Metode Sodis. Jurnal Kesehatan Prima.

Arsawan, M., Suyasa, I.W.B. dan Suarna, W., 2007, Pemanfaatan Metode Aerasi dalam Pengolahan Limbah Berminyak, Ecotrophic 2(2) : 1-9

Fatha, A., 2007, Pemanfaatan Zeolit Aktif untuk Menurunkan BOD dan COD Limbah Tahu, Universitas Negeri Semarang, Fakultas Matematika dan Ilmu Pengetahuan Alam, Semarang, (Skripsi).

Li, F. 2009. Treatment of Household Grey Water for non-potable Reuses. PhD Thesis. Hamburg University of Technology. Hamburg.

Peraturan Pemerintah Republik Indonesia Nomor 82 Tahun 2001 tentang Pengelolaan Kualitas Air dan Pengendalian dan Pencemaran Air. 
Puji dan Nur Rahmi. 2009. Pengolahan Limbah Cair Domestik Menggunakan Lumpur Aktif Proses Anaerob. Universitas Diponegoro, Fakultas Teknik. Semarang. (Skripsi)

Purwanti, I. F., Yoedihanto, G. dan Masduqi, A. 2003. Kinerja Digester Aerobik dan Pengering Lumpur dalam Mengolah Lumpur Tinja. Jurnal Purifikasi

Sudaryati, N.L.G., Kasa, I.W. dan Suyasa, I.W.B., 2007, Pemanfaatan Sedimen Perairan Tercemar sebagai Bahan Lumpur Aktif dalam Pengolahan Limbah Cair Industri Tahu, Ecotrophic 3(1) : 21-29

Susilawaty, A., Djaffar, M.H. Daud, A. 2007. Efektivitas Sistem Saringan Multimedia dalam Menurunkan TSS, BOD, $\mathrm{NH}_{3}-\mathrm{N}, \mathrm{PO}_{4}$ dan Total Coliform pada Limbah Cair Rumah Tangga. Jurnal Sains \& Teknologi.

Tabatabaei, Z., Mahvi, A. H., Saeedi, R., Khorshidi, A. R. and Sohrabi, A., 2007, Two-stage Sand Filtration of Secondary Effluent for Agricultural Reuse, International Journal of Agriculture \& Biology 9(6) : 889-892

Vigneswaran, S.and M. Sundaravadivel. 2004. Recycle and Reuse of Domestic Wastewater in Wastewater Recycle, Reuse, and Reclamation. Encyclopedia of Life Support System. 